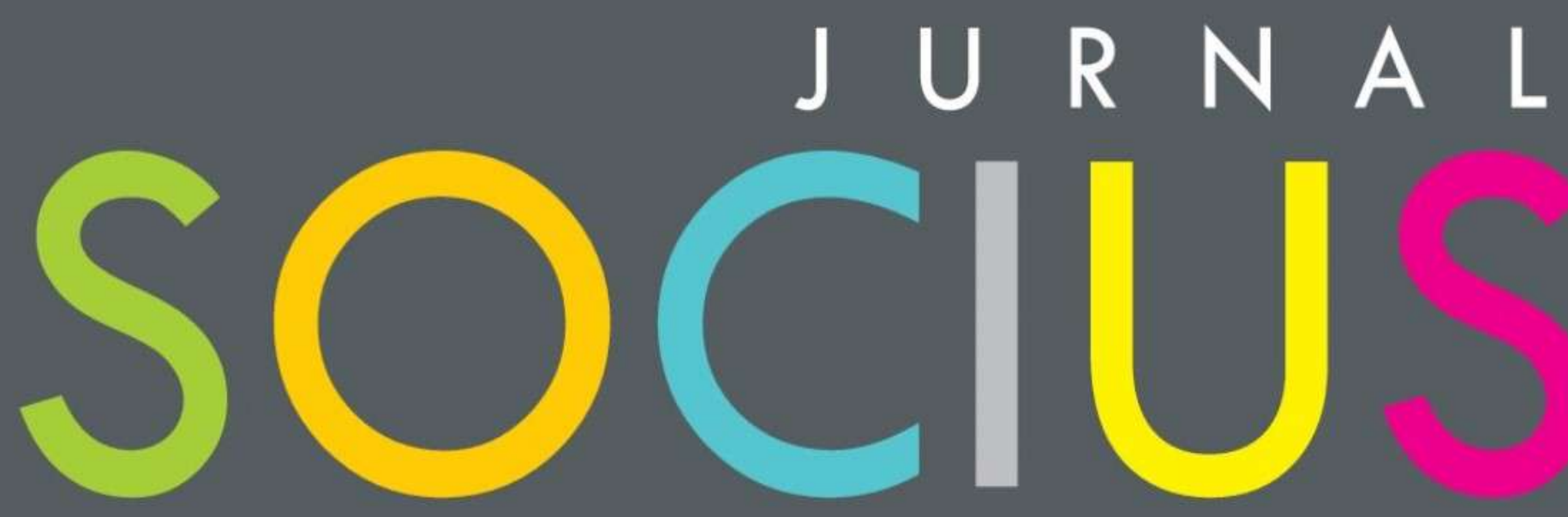

Journal of Sociology Research and Education

DITERBITKAN OLEH :

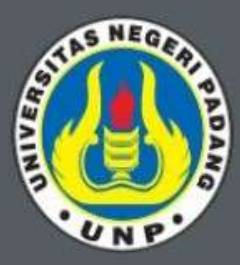

LABOR JURUSAN SOSIOLOGI FAKULTAS ILMU SOSIAL UNIVERSITAS NEGERI PADANG

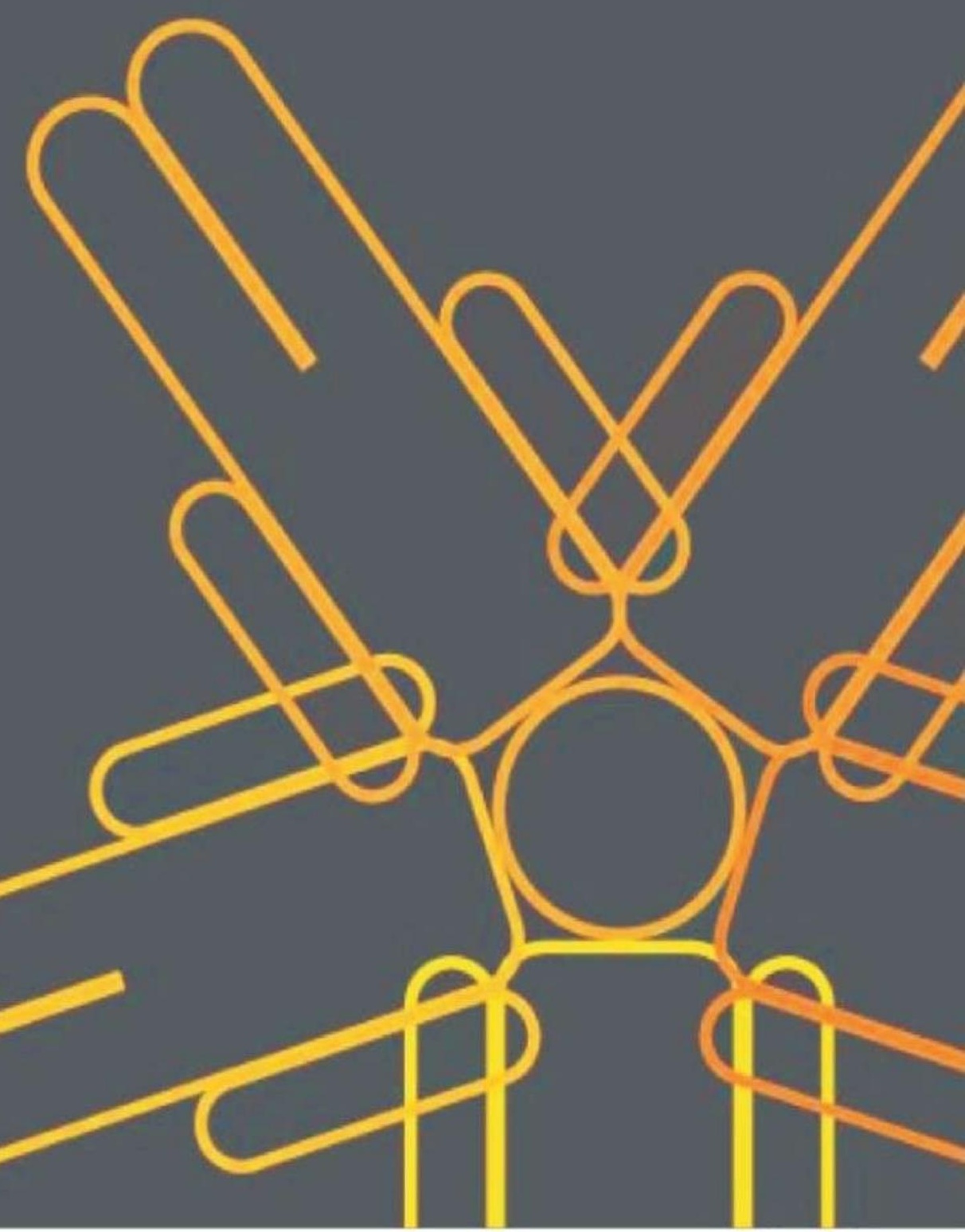




\section{SOCIUS}

Vol. 6, No.1, Th. 2019

ISSN : 2356-4180 (cetak)

2442-8663 (online)

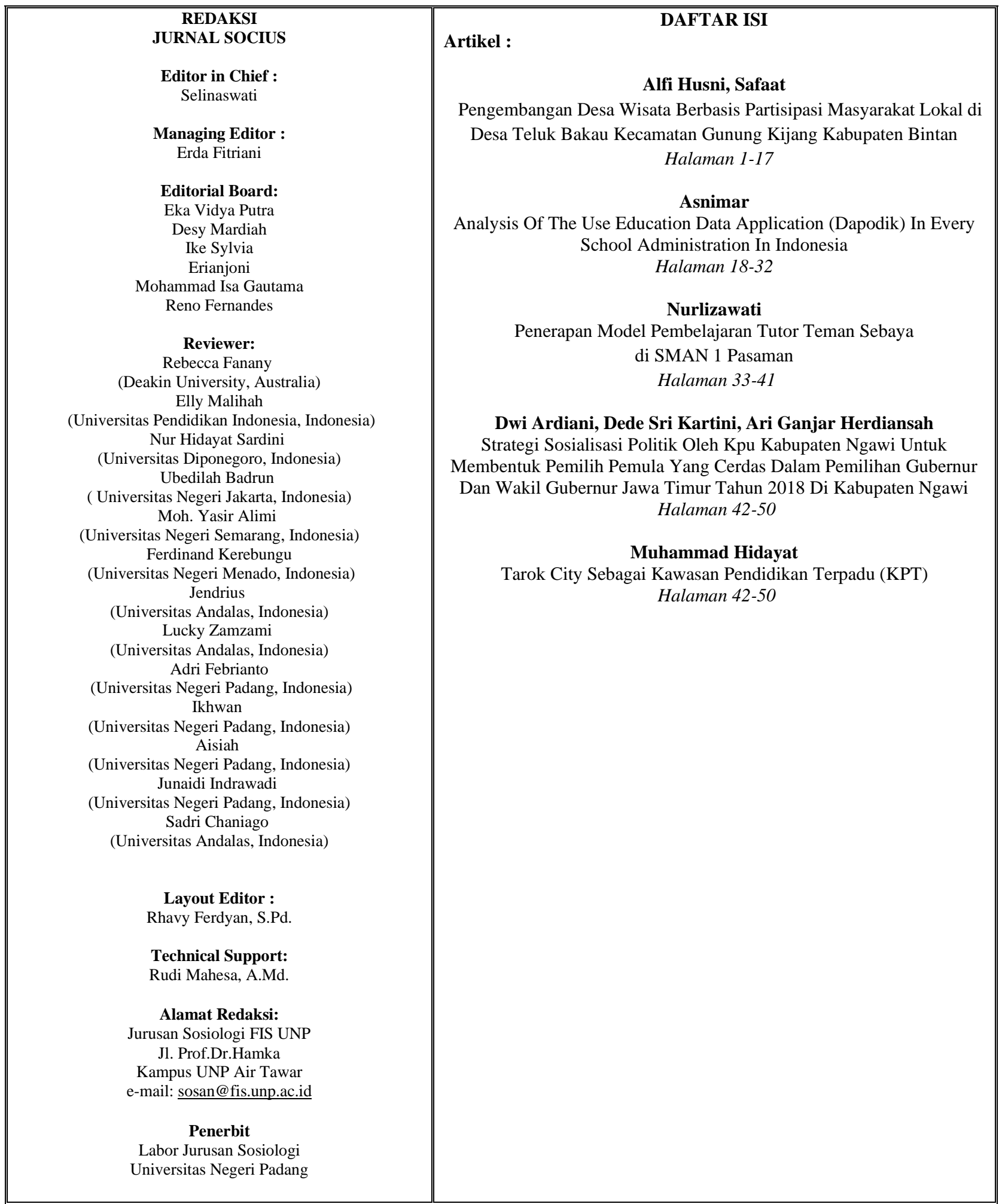




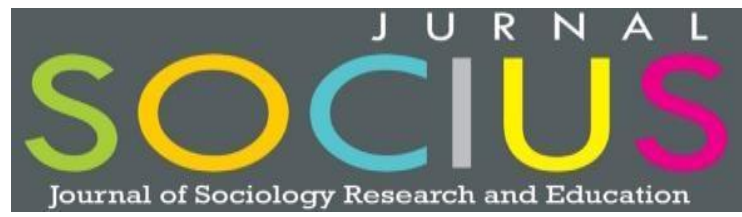

Jurnal Socius: Journal of Sociology Research and Education

Vol.6, No.1, Th. 2019

ISSN: Online 2442-8663 - Print 2356-4180

http://socius.ppj.unp.ac.id/index.php/socius

Email: socius@ppj.unp.ac.id

DOI: https://doi.org/10.24036/scs.v6i1.140

\title{
UPACARA NADZAR BATUMBANG APAM DI MAKAM KERAMAT GAJAH DESA KUBAH SENTANG
}

\author{
Noviy Hasanah ${ }^{1}$, Zuraidah $^{2}$ \\ 1,2Universitas Negeri Medan \\ Email: noviyhasanah@gmail.com
}

\begin{abstract}
Abstrak
Penelitian ini bertujuan untuk mengetahui upacara nadzar batumbang apam di makam Keramat Gajah Desa Kubah Sentang dusun I kecamatan Pantai Labu. Hasil dari penelitian ini mengungkapkan bahwa upacara nadzar batumbang apam adalah upacara yang diyakini masyarakat desa Kubah Sentang sebagai pembayaran nadzar atau janji terhadap suatu keinginan yang tercapai. Upacara nadzar batumbang apam tidak terlepas dari keberadaan Makam Keramat Gajah yang biasa dijadikan tempat dilakukannya upacara nadzar batumbang apam. Prosesi dari upacara nadzar batumbang apam di makam keramat gajah yang pertama mendatangi rumah pemimpin doa sembari menyampaikan tujuan atau hajatnya untuk batumbang apam, kemudian berjalan menuju makam, sesampainya dimakam pelepah kelapa yang telah ditusuki kue apam ditancapkan tanah di sisi makam yang diikuti dengan berdirinya orang yang akan dibatumbangkan, kemudian membaca basmallah, shalawat, al-fatihah, doa selamat, selanjutnya membagikan uang koin kepada anak-anak yang hadir pada saat upacara, dan diakhiri dengan memakan kue apam dan makanan lainnya yang telah didoakan bersama. Adapun pandangan masyarakat Desa Kubah Sentang terhadap upacara nadzar batumbang apam di makam Keramat Gajah yakni mereka menganggap adanya kekuatan ghaib di makam Keramat Gajah sehingga ketika melakukan nadzar mudah terkabul.
\end{abstract}

Kata kunci: Upacara, Nadzar, Batumbang apam

\section{Abstract}

The purpose of this study is to learn about the ceremony of Apam Nadzar Batumbang in the tomb of Keramat Gajah, in the village of Kubah, Sentang Village. By using indepth interview, observation and documentation as method in qualitative, the result of this study shows that the nadzar batumbang apam ceremony is a ceremony considering as a nadzar payment or the promise of a granted wish by this community. The ceremony of the nadzar batumbang apam is inseparable from the existence of the sacred tomb of elephants, which is generally used as the venue of the nadzar batumbang apam ceremony. The procession of the nadzar batumbang ceremony took place in front of the sacred tomb of the elephant. The rituals starting from visiting the house of preacher, then going together to the tomb, the person who has nadzar keep handing coconut leaf and then buried the coconut to the soil, then read basmallah, prayer, al-fatihah, and then distribute coins toward children attending the ceremony, and end up eating apam cakes and other foods that have been prayed for together. People in this community view that nadzar batumbang ceremony were in the tomb of Keramat Gajah is deserve do as well as they belief that the supernatural power of the sacred elephant cemetery gave them blessing and their wish will come true.

Keyword: Ceramony, Nadzar, Batumbang apam

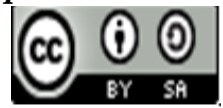

Received: January 8, 2019

Revised: June 29, 2019

Available Online: June 30, 2019

Jurnal Socius: Journal of Sociology Research and Education Vol. 6, No.1, Th. 2019

ISSN: Online 2442-8663 - Print 2356-4180 


\section{Pendahuluan}

Tradisi adalah perbuatan yang dilakukan berulang-ulang di dalam bentuk yang sama (Soekanto, 1990:181). Tradisi dapat diartikan sebagai warisan masa lalu. Indonesia memiliki tradisi yang bervariasi ataupun beragam. Setiap suku bangsa berada dalam kelompok masyarakat yang mempunyai tradisi yang berbeda-beda. Tradisi yang dimaksud ialah sebagai adat kebiasaan turun temurun yang masih dijalankan oleh sekelompok masyarakat. Masyarakat menjalani tradisi untuk mencapai suatu keadaan yang dianggap baik oleh pemilik kebudayaan. Bahkan pengharapan terciptanya kehidupan yang baik di dunia sering dipadukan dalam nuansa religius pada tradisi-tradisi suku bangsa tersebut.

Salah satu tradisi yang masih berkembang di masyarakat adalah tradisi nadzar batumbang apam. Batumbang apam adalah salah satu tradisi yang dilakukan masyarakat Banjar di Kalimantan Selatan. Tradisi batumbang apam merupakan tradisi yang mengandung unsurunsur Islami. Pada dasarnya tradisi ini adalah ungkapan rasa syukur atas kelahiran seorang anak, dengan harapan setelah melakukan tradisi ini sang anak akan cepat bisa berjalan dan tumbuh menjadi anak yang sehat, sholeh, dan menjadi anak yang berguna kelak di kemudian hari.

Tradisi batumbang apam pada masyarakat Banjar di Kalimantan Selatan merupakan tradisi turun temurun yang dilakukan pada saat Hari Raya Idul Fitri dan Hari Raya Idul Adha. Tempat pelaksanaan tradisi ini dilakukan masyarakat berbeda-beda, ada yang melakukannya di rumah dan sebagian besar masyarakat lainnya melakukannya di masjid keramat. Ada dua masjid keramat yang dijadikan tempat batumbang yakni Mesjid Keramat Pelajau dan Mesjid Al-A'la. Kedua masjid ini dijadikan sebagai tempat pelaksanaan batumbang apam karena kedua masjid ini merupakan masjid tertua di daerah Kalimantan Selatan.

Selain di Kalimantan Selatan, suku Banjar juga terdapat di daerah lain seperti di Sumatera Utara tepatnya di Desa Kubah Sentang Kecamatan Pantai Labu. Hasil penelitian Nasution (2017), Kedatangan masyarakat Banjar ke desa Kubah Sentang terjadi sekitar tahun 1903 yang kedatangannya di latar belakangi oleh terjadinya peperangan yang menyebabkan tidak memberi kenyamanan dan keamanan selain itu ada juga yang dibawa untuk menjadi buruh perkebunan dan buruh bangunan. Seperti halnya masyarakat Banjar di Kalimantan Selatan, masyarakat Banjar di Desa Kubah Sentang juga mengenal tradisi batumbang apam.

Pada Masyarakat Banjar di Kubah Sentang, tujuan dari batumbang apam adalah pelaksanaan nadzar atau janji yang harus ditepati saat seseorang sudah bernadzar. Kebanyakan di antara masyarakat yang ingin batumbang biasanya karena sakit. Saat yang bernazdzar sudah mendapatkan kesehatan atau mendapatkan apa yang diinginkan, yang bernadzar harus membayar nadzar dengan cara batumbang apam. Jika yang bernadzar tidak melaksanakan batumbang apam masyarakat setempat percaya akan terkena bala.

\section{Metodologi Penelitian}

\section{Informan Penelitian}

Pada penelitian ini, informan terbagi ke dalam beberapa aspek, yaitu informan kunci (key information) dan informan pendukung (supporting informant). Informan kunci (key informan) adalah orang yang memiliki pengetahuan mendalam tentang masalah yang akan dikaji. Dalam penelitian ini,tokoh masyarakat yang biasa memimpin doa dalam pelaksanaan tradisi nadzar batumbang apam dijadikan sebagai informan kunci. Informan tambahan dalam penelitian ini yaitu masyarakat yang sudah pernah melakukan tradisi nadzar batumbang apam Selain itu 
informan pendukung dalam penelitian ini dengan masyarakat yang belum pernah melakukan tradisi nadzar batumbang apam.

\section{Teknik Pengumpulan Data}

Teknik pengumpulan data merupakan cara yang dilakukanuntuk memperoleh dan mengumpulkan data yang dibutuhkan dalam penelitian. Untuk mendapatkan kelengkapan informasi yang sesuai dengan fokus penelitian ini, penelulis melakukan studi lapangan melalui: (1) observasi, (2) wawancara, (3) dokumentasi.

\section{Teknik Analisis Data}

Analisis data yang digunakan dalam penelitian ini adalah analisis data kualitatif. Analisis data yang digunakan yakni mengikuti konsep yang diberikan Miles and Huberman (dalam Sugiyono, 2012:246) mengungkapkan bahwa aktivitas dalam analisis data kualitatif dilakukan secara interaktif dan berlangsung secara terus menerus pada setiap tahapan penelitian sehingga sampai tuntas.Adapun proses yang dilakukan yaitu reduksi data, penyajian, interpretasi data, penyimpulan.

\section{Landasan Teori}

Andrew Lang adalah seorang ahli kesusastraan bangsa Inggris. Sebagai ahli kesusastraan, Lang telah banyak membaca tentang kesusastraan rakyat dari banyak suku bangsa di dunia. Di dalam dongeng-dongeng itu Lang sering mendapatkan adanya tokoh dewa yang oleh suku-suku bangsa bersangkutan dianggap dewa tertinggi, pencipta seluruh alam semesta serta isinya, dan penjaga ketertiban alam dan kesusialaan. Berbagai hal membuktikan bahwa kepercayaan itu tidak timbul sebagai akibat pengaruh agama Nasrani atau Islam, maka kepercayaan tadi malahan tampak seolah-olah terdesak kebelakang oleh kepercayaan kepada makhluk-makhluk halus, dewa-dewa alam, ruh, hantu, dan sebagainya. A. Lang berkesimpulan bahwa kepercayaan kepada dewa tertinggi adalah suatu kepercayaan yang sudah amat tua, dan mungkin merupakan bentuk religi manusia yang tertua. Adapun pendiriannya itu diumumkan dalam beberapa karangan antara lain dalam buku yang berjudul The Making of Religion (1898).

Buku The Making of Religion terdiri dari dua bagian, yang satu mengenai gejala pada psikologi, dan yang kedua mengenai keyakinan yang ada pada banyak suku bangsa primitif mengenai "tokoh dewa tertinggi". Bagian kedua dari buku Lang mengandung suatu uraian mengenai folklore (ilmu asal-usul bangsa), dan metologi suku-suku bangsa di berbagai daerah di muka bumi. Dalam dongeng-dongeng metologi itu Lang sering menemukan adanya tokoh dewa yang oleh suku-suku yang bersangkutan dianggap dewa tertinggi (Supreme Being, High God). Penciptaan alam semesta beserta isinya, penjaga alam dan kesusilaan.

Teori ini dinyatakan dalam bukunya The Making of Religion (1998) yang dikutip oleh Ali sebagai berikut:

Of the existence of a belief in a Supreme Being among primitive tribes there is a good evidence as we posses for any in the ethnographic religion we shall show that certain low ages are as monotheistic as some Christian. They have a Supreme Being and the distristive attributes of Deity are not by them assigned to other beings.

(Tentang adanya wujud agama di antara suku-suku primitif terdapatlah bukti yang baik kita miliki bagi tiap kenyataan dalam daerah etnografi. Kita akan menunjukkan bahwa 
orang-orang biadab yang rendah tertentu adalah sama monoteisnya sebagaimana sebagian dari orang-orang Kristen. Mereka mempunyai wujud yang Agung dan sifat-sifat yang khas. Ketuhanan tidak diberikan oleh mereka kepada makhluk lain).

Sehubung dengan hal tersebut, Koentjaraningrat (2002) para pengarang etnografi yang datang dalam masyarakat suatu suku bangsa tertentu, akan segera tertarik akan upacara-upacara keagamaan suku bangsa, karena upacara-upacara itu pada lahirnya tampak berbeda sekali dengan upacara keagamaan dalam agama bangsa-bangsa Eropa itu sendiri, yakni agama Nasrani. Dalam usaha untuk memecahkan masalah asal mula religi, para ahli biasanya menganggap religi sukusuku bangsa di luar Eropa sebagai sisa-sisa dari bentuk-bentuk religi yang kuno, yang dianut oleh orang Eropa ketika kebudayaan mereka masih primitif.

Semua aktifitas manusia yang bersangkutan dengan religi berdasarkan atas suatu getaran jiwa, yang biasanya disebut emosi keagamaan. Emosi keagamaan itulah yang mendorong orang melakukan tindakan-tindakan yang bersifat religi. Pokok emosi keagamaan menyebabkan bahwa suatu tindakan, atau suatu gagasan, mendapat suatu nilai keramat, atau sacred value dan dianggap keramat. Dengan demikian emosi keagamaan merupakan unsur penting dalam suatu religi bersama dengan tiga unsur yang lain, yaitu sistem keyakinan, sistem upacara keagamaan, suatu umat yang menganut religi itu.

Sistem upacara kegamaan secara khusus mengandung empat aspek : tempat upacara keagamaan dilakukan, saat-saat upacara keagamaan dijalankan, benda-benda dan alat upacara, orang-orang yang melakukan dan memimpin upacara.Berhubungan dengan tempat-tempat keramat dimana upacara dilakukan, yaitu makam, candi, pura, kuil gereja, langgar, surau, masjid dan sebagainya. Upacara - upacara itu sendiri juga banya unsurnya, yaitu (i) bersaji, (ii) berkorban; (iii) berdoa; (iv) makan bersama makanan yang telah disucikan dengan doa; (v) menari tarian suci; (vi) menyanyi nyanyian suci; (vii) berprosesi atau berpawai; (viii) memainkan seni drama suci; (ix) berpuasa (x) intoksidasi (xi) bertapa; (xii) bersemedi.

\section{Hasil dan Pembahasan}

\section{Upacara Nadzar Batumbang Apam di makam Keramat Gajah Desa Kubah Sentang}

Upacara nadzar batumbang apam adalah upacara yang diyakini masyarakat desa Kubah Sentang sebagai pembayaran nadzar atau janji terhadap suatu keinginan yang tercapai. Misalnya jika seorang Ibu bernadzar ketika anaknya sakit, kelak jika anaknya sehat dia akan membawa anaknya batumbang ke makam keramat gajah yang terletak di desa Kubah Sentang Dusun I.

Sebagian masyarakat masih menjalankan batumbang apam ini, terutama kaum tua. Mereka percaya jika dengan bernadzar apa yang diinginkannya dapat tercapai. Namun, jika tidak membayar nadzar tersebut kelak di kemudian hari akan mendapat bala. Namun, sebagian masyarakat juga tidak mempercayai hal ini, karena bagi sebagian masyarakat misalnya untuk memperoleh kesehatan tidak harus dengan melakukan nadzar melainkan minum obat atau berobat ke dokter, serta tidak pula lupa untuk selalu berdoa kepada Tuhan Yang Maha Esa. Upacara nadzar batumbang apam di makam Keramat Gajah desa Kubah Sentang Dusun I Kecamatan Pantai Labu tidak terlepas dari keberadaan Makam Keramat Gajah yang biasa dijadikan tempat dilakukannya upacara nadzar batumbang apam.

Jurnal Socius: Journal of Sociology Research and Education Vol. 6, No.1, Th. 2019 ISSN: Online 2442-8663 - Print 2356-4180 


\section{Persiapan pelaksanaan upacara nadzar batumbang apam di makam Keramat Gajah desa Kubah Sentang dusun I Kecamatan Pantai Labu}

Upacara nadzar batumbang apam di makam Keramat Gajah Desa Kubah Sentang memiliki beberapa tahan dalam pelaksanaannya. Adapun tahap pelaksanaan dari upacara nadzar batumbang apam di makam Keramat Gajah maka diperlukan tahap-tahap berikut agar dapat melakukan upacara nadzar batumbang apam yaitu :

\section{Memiliki nadzar}

Menurut KBBI (Kamus Besar Bahasa Indonesia) nadzar atau nazar memiliki arti janji (pada diri sendiri) hendak berbuat sesuatu jika maksud tercapai. Dalam hal ini, nadzar yang dilakukan seseorang merupakan suatu hajat yang apabila tercapai nantinya akan melakukan batumbang apam di makam Keramat Gajah. Masyarakat yang ingin batumbang, tentunya memiliki nadzar yang berbeda-beda. Beberapa di antara nadzar yang sering dilakukan itu biasanya karena sakit, kenaikan jabatan, perihal jodoh, momongan, permasalahan rumah tangga.

\section{Mempersiapkan segala sesuatu yang dibutuhkan sebelum melakukan upacara nadzar batumbang apam di makam Keramat Gajah}

Adapun hal yang dipersiapkan masyarakat yang ingin melakukan upacara nadzar batumbang apam di makam Keramat Gajah yaitu:

1. Pelepah Kelapa

Pelepah kelapa yang akan digunakan dalam upacara nadzar batumbang apam harus memiliki tinggi yang sama dengan tinggi orang yang dibatumbangkan. Jumlah pelepah kelapa yang disiapkan hanya satu pelepah untuk setiap orang yang akan dibatumbangkan. Selanjutnya daun yang ada di pelepah kelapa akan diserut hingga menyisahkan lidi yang nantinya akan ditancapkan kue apam ke setiap lidinya.

2. Kue apam

Kue apam dalam masyarakat Banjar desa Kubah Sentang selalu menjadi pelengkap dalam beberapa hajatan atau acara yang dilakukan masyarakat, di antaranya acara selametan, pernikahan, kumpul keluarga, serta dalam upacara nadzar batumbang apam. Kue ini menjadi hal utama yang harus dipersiapkan dalam upacara nadzar batumbang apam. Kue apam yang sudah dibuat oleh keluarga yang akan melakukan upacara batumbang apam nantinya akan dipotong kecil untuk selanjutnya ditusuk ke lidi yang ada di pelepah kelapa, dan selanjutnya akan didoakan setibanya sampai di makam Keramat Gajah setelah itu nantinya akan dimakan bersama.

3. Beras kuning

Beras kuning merupakan beras yang diwarnai dengan kunyit, beras ini natinya akan menjadi campuran uang receh yang dibagikan kepada anak-anak yang hadir di upacara nadzar batumbang apam di makam Keramat Gajah

4. Uang receh

Uang receh atau uang koin juga merupakan salah satu hal yang dipersiapkan sebelum upacara nadzar batumbang. Uang ini nantinya akan dibagi-bagikan kepada anak-anak yang ikut dalam upacara tersebut.

5. Makanan lainnya

Selain kue apam biasanya masyarakat yang melakukan upacara nadzar batumbang apam juga membawa makanan lain, misalnya pulut kuning, ayam panggang yang nantinya akan ikut 
dido'akan dalam prosesi upacara nadzar batumbang apam. Namun, tidak semua keluarga yang melakukan batumbang menyiapkan makanan ini, semua tergantung kepada kesanggupan keluarga yang memiliki niat untuk melakukan upacar nadzar batumbang apam.

\section{Prosesi pelaksanaan upacara nadzar batumbang apam di makam Keramat Gajah desa Kubah Sentang dusun I kecamatan Pantai Labu}

Setiap upacara tentunya memilki prosesi pelaksanaan, dalam hal ini dalam pelaksanaan upacara nadzar batumbang apam tidak terlepas dari prosesi pelaksanaan upacara, diantaranya yaitu:

1. Mendatangi Pemimpin Do'a

Biasanya masyarakat yang ingin batumbang apam langsung mendatangi rumah pemimpin doa, kemudian yang bernadzar menceritakan apa tujuannya mendatangi rumah pemimpin do'a. Batumbang apam tidak memiliki waktu yang khusus, jika ingin batumbang pada hari yang sama saat mendatangi rumah pemimpin doa, langsung pada hari itu juga dapat dilaksanakannyaupacara nadzar batumbang apam.

2. Mendatangi makam Keramat Gajah

Selanjutnya setelah menceritakan tujuannya untuk batumbang apam, kemudian keluarga yang ingin batumbang apam langsung dibawa pemimpin doa ke makam Keramat Gajah yang merupakan tempat dilakukannya upacara nadzar batumbang apam. Setibanya di makam kemudian orang yang ingin ditumbangkan berdiridan pelepah kelapa yang ditusuki kue apam yang telah dipersiapkan sebelumnya juga diberdirikan di belakang orang yang dibatumbangkan. Pelepah kelapa tersebut juga ditancapkan ke tanah di sisi samping makam.

3. Membaca Basmallah dan Shalawat Nabi

Selanjutnya pemimpin doa memulai untuk upacara nadzar batumbang apam, dimulai dari pembacaan basmallah. Dalam ajaran agama Islam, segala sesuatu hendaknya dimulai dengan bacaan basmallah. Begitu juga dengan pelaksanaan upacara nadzar batumbang apam di makam Keramat Gajah. Setelah membacakan basmallah kemudian, orang yang dibatumbangkan bersama dengan pelepah kelapa yang telah ditusuki kue apam dibacakan shalawat nabi sebanyak tiga kali dan diikuti juga dengan orang yang sedang dibatumbangkan keluarga dan masyarakat yang hadir di tempat upacara nadzar batumbang apam. Sembari membacakan shalawat, pemimpin doa menaburkan beras kuning keatas kepala orang yang sedang dibatumbangkan.Maksud dari pembacaan shalawat nabi ini diharapkan kelak di hari akhir yang membacakan shalawat nabi akan mendapatkan syafa'at.

4. Membaca Surah Al-Fatihah

Prosesi selanjutnya setelah membaca basmallah dan shalawat nabi yaitu membaca surah alfatihah. Surah al-fatihah dibaca karena di dalam ajaran agama Islam, surah ini memiliki kedudukan yang tertinggi didalam Al-qur'an atau biasa disebut sebagai ummul qur'an yang artinya induk qur'an.

5. Membaca Do'a Selamat

Membacakan do'a selamat merupakan rangkaian prosesi upacara nadzar batumbang selanjutnya. Pembacaan do'a ini masih dipimpin oleh Kakek Sahran, do'a ini bertujuan agar kiranya orang yang sedang dibatumbangkan dan seluruh orang yang hadir dalam prosesi upacara diberikan keselamatan, kesehatan dan diberikan kehidupan yang baik.

Jurnal Socius: Journal of Sociology Research and Education Vol. 6, No.1, Th. 2019 


\section{Membagikan Uang Koin}

Prosesi selanjutnya dalam upacara nadzar batumbang apam adalah membagikan uang koin. Pembagian uang koin ini dilakukan setelah melakukan serangkaian do'a-do'a di atas. Pembagian uang koin ini diberikan kepada anak-anak yang berhadir dalam upacara nadzar batumbang apam, dengan tujuan sebagai rasa syukur dan berbagi rezeki kepada sesama.

7. Memakan kue apam dan makanan lainnya

Untuk prosesi yang terakhir adalah memakan kue apam yang ikut dido'akan dalam rangkaian upacara. Kue apam akan dibagikan dan dimakan bersama dengan orang yang hadir di upacara nadzar batumbang apam. Selain kue apam, keluarga yang melakukan batumbang apam apabila memiliki rezeki yang berlebih dapat juga menyediakan makanan lain.

\section{Pandangan masyarakat Desa Kubah Sentang terhadap upacara nadzar batumbang apam}

Pandangan masyarakat artinya penilaian masyarakat, persepsi masyarakat dalam memandang, menilai, mengamati sesuatu. Dalam hal ini masyarakat desa Kubah Sentang memiliki pandangan terhadap upacara nadzar batumbang apam yaitu di antaranya masyarakat meyakini adanya kekuatan ghaib dari makam keramat gajah yang menjadi tempat dilakukannya upacara tersebut. Makam tersebut dijadikan perantara atas segala permintaan masyarakat yang biasa mereka lakukan dengan bernadzar.

Masyarakat memiliki pandangan terhadap upacara nadzar batumbang apam di makam keramat gajah yaitu dengan melakukan batumbang apam segala hajat atau do'a akan tercapai karena melakukan nadzar untuk batumbang apam di makam Keramat Gajah yang dianggap masyarakat sebagai jalan terkabulnya doa dengan berbagai hajat. Jasad yang ada di dalam makam Keramat Gajah ini juga yang dianggap memiliki pengaruh besar atas terkabulnya hajat dari masyarakat yang bernadzar. Mereka menganggap jasad tersebut adalah orang yang baik, sholeh sehingga menjadi perantara tercapainya hajat atau nadzar.

Selain itu, pandangan masyarakat terhadap ritual nadzar batumbang apam di makam Keramat Gajah ini adalah selain upacara penebusan nadzar juga sebagai ziarah ke makam Keramat Gajah sembari berdoa di makam tersebut. Pandangan masyarakat lainnya yaitu, sebagai ungkapan rasa syukur atas segala pencapaian yang telah diberikan Yang Maha Kuasa kepada mereka, seperti halnya kesembuhan dari suatu penyakit. Tidak hanya itu batumbang apam juga dianggap sebagai sedekah dan juga ajang silaturahmi, dilihat saat melakukan upacara ini beberapa masyarakat sekitar juga ikut berkumpul untuk menghadiri upacara tersebut, sedangkan sedekah disini adalah orang yang melakukan upacara nadzar batumbang apam memberikan uang kepada anak-anak yang datang dan makan bersama kue apam dan makanan lainnya dengan masyarakat yang berhadir. Dengan melakukan sedekah merupakan salah satu bentuk rasa syukur masyarakat dengan berbagi kepada sesama.

Namun kini, karena semakin berkembangnya zaman merubah pola fikir masyarakat akan kepercayaan supranatural. Mereka kini lebih beranggapan jika memohon kesembuhan atau keselamatan lebih percaya kepada Allah Swt. Di samping itu, kini masyarakat Desa Kubah Sentang lebih memilih pengobatan medis yang dianggap lebih memiliki efek penyembuhan yang lebih cepat dan penyakit dapat diketahui dengan berbagai alat canggih dari pihak medis.

Berkaitan dengan teori yang dikemukakan oleh Andrew Lang dalam bukunya yang berjudul The Making of Religion (1989) menyatakan bahwa adanya sosok yang memiliki kekuatan supernatural menimbulkan sosok yang dianggap dewa oleh manusia. Lang menambahkan bahwa kemampuan gaib yang dimiliki manusia ini memunculkan konsep jiwa.

Jurnal Socius: Journal of Sociology Research and Education Vol. 6, No.1, Th. 2019 
Pada masyarakat Desa Kubah Sentang mereka mempercayai adanya kekuatan gaib terhadap makam Keramat Gajah yang diajadikan tempat berlangsung upacara nadzar batumbang apam. Sosok yang ada di dalam makam tersebut dianggap memiliki kekuatan dengan tercapainya nadzar-nadzar atau hajat yang dilakukan masyarakat yang apabila tercapai akan melakukan sebuah upacara yang biasa disebut dengan batumbang apam oleh masyarakat setempat. Dalam upacara nadzar batumbang apam masyarakat membuat sesaji yakni kue apam yang ditusuk pada pelepah kelapa. Selain itu masyarakat yang akan melakukan upacara nadzar batumbang apam juga meyediakan uang receh yang sudah didoakan bersama untuk nantinya dibagikan kepada anak-anak yang hadir di upacara tersebut. Dalam menyampaikan permohonan nadzarnya masyarakat juga harus memiliki keyakinan seraya berdoa agar nadzar yang disampaikan dapat tercapai. Selain itu nadzar yang disampaikan haruslah nadzar yang positif seperti kesembuhan penyakit, karena apabila meyampaikan nadzar atau datang ke makam dengan memohon dalam hal yang negatif biasanya tidak akan tercapai. Upacara nadzar batumbang apam ini juga sebagai bentuk rasa syukur terhadap segala hajat yang telah tercapai, dengan melakukan berbagai macam doa-doa dan membagikan makanan, uang kepada masyarakat yang hadir. Dengan begitu, masyarakat yang hadir kiranya juga memberikan doa kepada keluarga yang bernadzar untuk keselamata, rezeki, dan kesehatan.

\section{Penutup}

Pelaksanaan upacara nadzar batumbang apam di makam Keramat Gajah yaitu harus memiliki nadzar dalam hal ini biasanya masyarakat lebih cenderung bernadzar untuk kesembuhan penyakit. Tahap selanjutnya adalah membawa segala hal yang sudah dipersiapkan sebelum datang ke rumah sang pemimpin doa, seperti kue apam yang sudah ditusuk ke pelepah kelapa yang memiliki tinggi sesuai dengan tinggi orang yang akan dibatumbangkan, kemudian membawa uang receh dan makanan lainnya jika ada. Setelah semua persiapan itu sudah terpenuhi kemudian keluarga yang ingin batumbang apam mendatangi rumah sang pemimpin doa untuk menjelaskan nadzar yang telah tercapai kepada sang pemimpin doa. Setelah itu sang pemimpin doa akan membawa keluarga yang akan melalukakan upacara ke makam Keramat Gajah yang tidak jauh dari rumahnya. Sesampainya di makam, orang yang dibatumbangkan akan berdiri disamping makam dan pelepah kelapa yang telah ditusuki kue apam yang selanjutnya pelepah tersebut ditancapkan ke tanah samping makam. Kemudian setelah itu pemimpin doa akan membacakan Basmallah dan Shalawat Nabi, membaca Surah Al-Fatihah, membaca Do'a Selamat. Setelah membacakan serangkaian doa kemudian prosesi selanjutnya membagikan Uang Koin kepada anak-anak yang hadir pada saat upacara nadzar batumbang apam tersebut, hal ini dianggap sebagai sedekah karena ungkapan rasa syukur atas tercapainya nadzar yang telah dilakukan. Kemudian setelah itu memakan kue apam dan makanan lainnya yang telah didoakan bersama saat upacara berlangsung.

Pandangan masyarakat Desa Kubah Sentang terhadap upacara nadzar batumbang apam di makam Keramat Gajah yakni mereka menganggap adanya kekuatan ghaib di makam Keramat Gajah sehingga ketika melakukan nadzar mudah terkabul. Pandangan masyarakat lainnya, bahwasannya jasad yang ada di dalam makam merupakan orang sholeh dan memiliki kepribadian yang baik sehingga ketika masyarakat bernadzar mudah untuk terkabul. Selain itu, batumbang apam ini juga memiliki tujuan untuk berziarah serta mendoakan jasad yang ada di dalam makam tersebut. Namun demikian, kini batumbang apam sudah sangat jarang dilakukan

Jurnal Socius: Journal of Sociology Research and Education Vol. 6, No.1, Th. 2019 ISSN: Online 2442-8663 - Print 2356-4180 
oleh masyarakat setempat ataupun masyarakat yang dari luar kota. Hal ini dikarenakan semakin berkembangnya zaman, merubah pola fikir masyarakat akan kekuatan supranatural semakin berkurang. Jika ada yang sakit kini masyarakat cenderung memilih pengobatan medis yang lebih memiliki efek penyembuhan yang lebih cepat dan tepat.

\section{Daftar Pustaka}

Amar, Imron Abu. (1983). Fathul Qarib. Kudus: Menara Kudus.

Basrowi dan Suwandi. (2008). Memahami Penelitian Kualitatif. Jakarta: Rineka Cipta

Dhavamony, Mariasusai. (2006). Fenomenologi Agama. Yogyakarta: Kasinius.

Kamal, Abu Malik. (2016). Fiqih Sunnah Wanita. Jakarta: Griya Ilmu.

Koentjaraningrat.(1985). Beberapa Pokok Antropologi Sosial. Jakarta: PT.Dian Rakyat. . (2002). Pengantar Antropologi Pokok-Pokok Etnografi II. Jakarta: Rineka

Cipta. . (2002). Pengantar Ilmu Antropologi. Jakarta: Rineka Cipta. . (2004). Kebudayaan Mentalitas dan Pembangunan. Jakarta: Gramedia.

Moleong, L. J. (2000). Metodologi Penelitian Kualitatif. Bandung: PT Remaja Rosdakarya.

Simanjuntak, Nancy. (1986). Antropologi Sosial. Jakarta: Bumi Aksara.

Soekanto, Soerjono. (1990). Sosiologi Suatu Pengantar. Jakarta: Rajawali Press.

Sugianto, Eko. (2015). Menyusun Proposal Penelitian Kualitatif Skripsi dan Tesis. Yogyakarta: Suaka Media.

Sugiyono. (2012). Metode Penelitian Kualitatif dan R\&D. Bandung: Alfabeta.

Yusuf, Muri. (2014). Metode Penelitian: Kuantitatif, Kualitatif, dan Penelitian Gabungan. Jakarta: Kencana. 